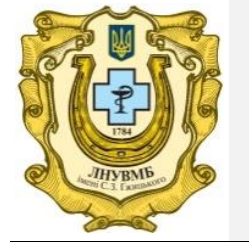

Ukrainian Journal of

Veterinary and Agricultural Sciences

http://ujvas.com.ua

Stepan Gzhytskyi National University of Veterinary Medicine and Biotechnologies Lviv

original article $\quad$ UDC 619: 615-614.9 | doi: 10.32718/ujvas1-1.04

Volume 1

Number 1

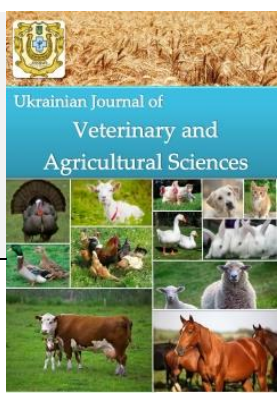

\title{
Influence of HammecoTox and Zeolitis on morphological and biochemical indicators of rat's blood under conditions of experimental fumonisin toxicosis
}

\author{
O.M. Brezvyn, G.V. Rudyk, Z.A. Guta
}

State Scientific-Research Control Institute of Veterinary Medicinal Products and Feed Additives, Donetska Str., 11, Lviv, 79019, Ukraine

\begin{tabular}{l} 
Article info \\
Received 20.04.2018 \\
Received in revised form \\
05.06.2018 \\
Accepted 11.06.2018 \\
\hline Correspondence author \\
Zoryana Guta \\
Tel.: +38-098-812-57-45 \\
E-mail: guta1985@ukr.net \\
\hline
\end{tabular}

(C) 2018 Brezvyn O. et al. This is an open-access article distributed under the terms of the Creative Commons Attribution License, which permits unrestricted use, distribution, and reproduction in any medium, provided the original author and source are credited.

\section{(cc) BY}

Contents

1. Introduction .................. 23

2. Materials and methods ....... 24

3. Results and discussion ...... 24

4. Conclusions ................ 28

References .................... 28

\begin{abstract}
In the article the peculiarities of the influence of fodder additives HammecoTox and Zeolit on the organism of rats under conditions of experimental chronic fumonisin toxicosis are given. The research was carried out under vivarium of State Scientific-Research Control Institute of Veterinary Medicinal Products and Feed Additives. In the experiment, 40 rats of body weight $165-170$ g. were used. 4 groups were formed. First group of animals was control, in experimental II, III, and IV groups of animals chronic fumonisin toxicosis was reproduced. Rats were injected intragastrically daily of $90 \mathrm{mg}$ of fumonisin per animal. After the manifestation of clinical signs of fumonisin toxicosis on the 21st day, animals of groups III-IV began to feed fodder additives, respectively, rats from group III - HammecoTox, IV - Zeolit. After injection of fumonisin to experimental rats, the morphofunctional state of animals has been gradually changing since the first days. Clinical picture of fumonisin toxicosis in experimental rats at day 14 was manifested by dermo-necrotic effect, it was observed redness and formation of crust on visible mucous membranes, nose, showed swelling and redness of the forelocks. After the analysis of the obtained results of hematological researches on the 14th day in rats of group II under the conditions of experimental fumonisin toxicosis, was revealed a probable increase in the number of leukocytes, was established a tendency for growth, the number of eosinophils, segmental neutrophils, as well as a decrease in the number of lymphocytes, monocytes, compared with the control group. In the analysis of leukograms was noted a tendency to shift the nucleus to the left. These results indicated the presence of inflammatory processes and reduced immune protection of the organism of animals in general. After using of feed additives of HammecoTox and Zeolit under conditions of fumonisin toxicosis, of particular note is the stabilization of hematological parameters, the content of hematocrit, the number of leukocytes, the increase in the content of eosinophils and lymphocytes, which reflects the activation of hematopoiesis in the organism of experimental animals and its protective factors. An increase in the urea content in these groups indicates the recovery of urea-synthesis and urea-excretory liver function. In general, for the period of the conducted searches, the effectiveness of both feed additives in the experimental fumonisin toxicosis has been established. However, it should be noted that more active processes of normalizing the clinical condition of experimental rats when using HammecoTox, which is due to the complex influence of the means on the organism of animals.
\end{abstract}

Key words: toxicology, rat, fumonisin, HammecoTox, Zeolite, hematological parameters.

\section{Citation:}

Brezvyn, O.M., Rudyk, G.V., \& Guta, Z.A. (2018). Influence of HammecoTox and Zeolitis on morphological and biochemical indicators of rat's blood under conditions of experimental fumonisin toxicosis. Ukrainian Journal of Veterinary and Agricultural Sciences, 1(1), 2329.

\section{Introduction}

Fumonisins - a group of mycotoxins that have a nephrotoxic effect, which causes encephalomalacia and changes in the leukocyte content of blood (Fravalo et al., 2013; Guta, 2015; Guerre, 2015; Nleya et al., 2018). Fumonisins destroy cell membranes, which in the first place leads to damage of the liver and kidneys of farm animals. In poultry, fumonisins often lead to the development of the so-called syndrome of toxic fodder, which includes motor disturbances and growth retardation (Kim et al., 2013; Guta, 2016; Grenier et al., 2016).
The most practical methods of detoxification of mycotoxins in livestock and poultry farming are based on the use of sorbents with damaged feeds (Ruda and Vasianovych, 2012; Brezvyn et al., 2013). The latter reduce the biological activity of mycotoxins, reduce the absorption of toxins in the digestive tract of animals, protect the produce from contamination (Kotsiumbas et al., 2010; Hoister et al., 2013). It should be noted, that a large number of medical and prophylactic drugs have been created at present. We emphasize that the development of prevention and treatment methods using enterosorbents also requires constant improvement. Although all sorbents, one way or another, are passive absorbers of mycotoxins, but the effectiveness of their actions 
remains the subject of sharp discussions of scientists (Berezovskyi et al., 2014). On the pages of various editions is constantly emphasized on the ability of sorbents to bind and remove from the body of animals mycotoxins, but none of these sorbents completely solves the problem, and animals still feed damaged feeds with mycotoxins and according to the existing clinical picture, they are treated with antibiotics, as a consequence, in addition to existing problems, other unwanted side effects are obtained.

The foregoing has allowed us to determine the following areas of research of feed additives - sorbents of mineral origin. The purpose of our research was to investigate the influence of HammecoTox and Zeolit on the body of rats under the experimental fumonisin toxicosis.

\section{Materials and methods}

The research was carried out under vivarium of State Scientific-Research Control Institute of Veterinary Medici- nal Products and Feed Additives. In the experiment, 40 rats were used of body weight $165-170$ g. 4 groups were formed. First - the group of animals served as control, in experimental II, III, and IV groups of animals was reproduced chronic fumonisin toxicosis. Rats received daily intravenous injection of $90 \mathrm{mg}$ of fumonisin per animal. After the clinical signs of fumonisin toxicosis at day 21 , animals of groups III-IV began feeding feed additives, respectively, to the rats of group III - HammecoTox, IV - Zeolitis (Fig. 1).

During the experiment, observations were made of the behavior of animals, their clinical condition and death were shown. At the 14th and 21 st day of the experiment rat were weighing and blood was collected for hematological, immunological and biochemical studies, by decapitation, under a slight, etheric anesthetic, following the position of the European Convention for the Protection of Vertebrate Animals, which are used in experiments and other scientific purposes (Strasbourg, 1986).
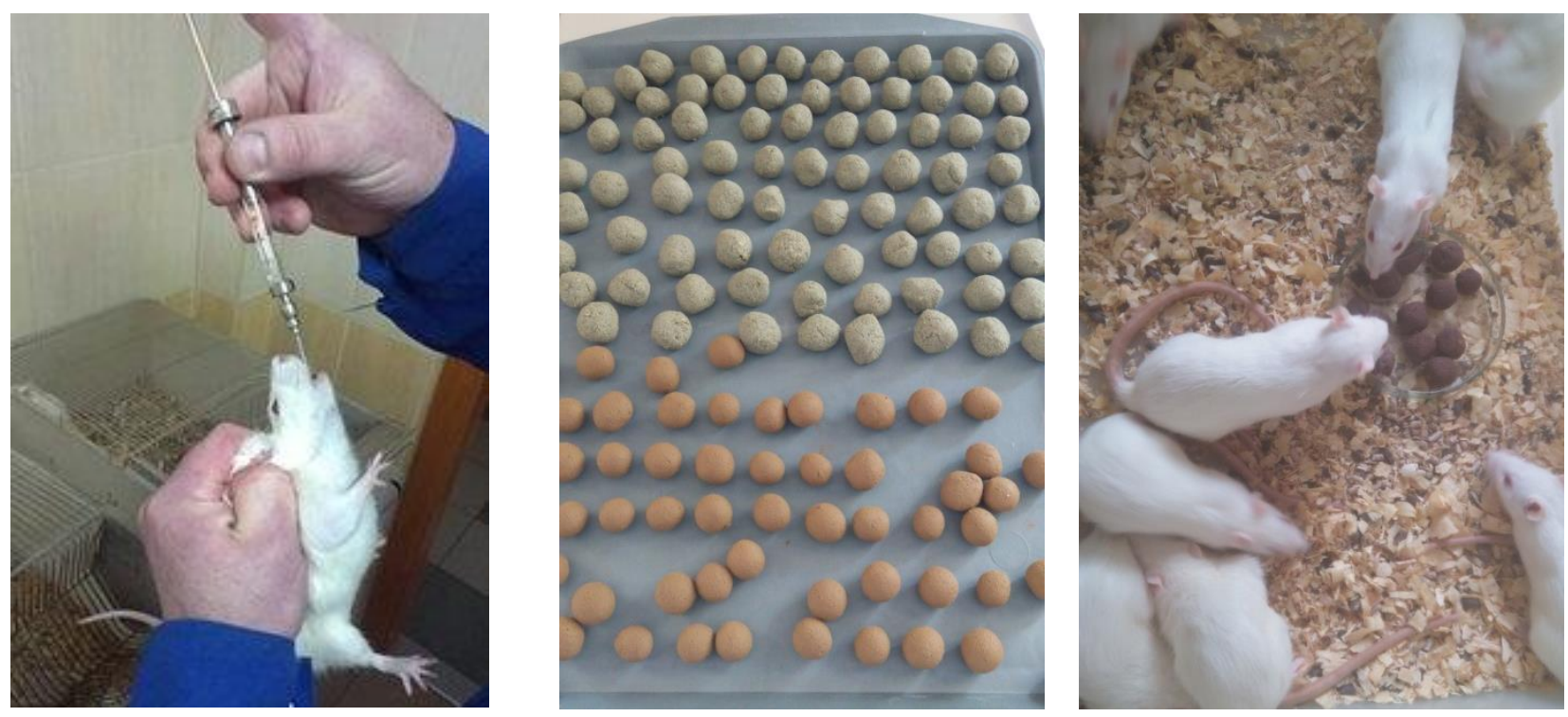

Fig. 1. Rat. Toxin introduction in II, III, IV - groups. Preparation and Feeding of Feed Additives HammecoTox and Zeolite

After the blood samples were taken, all the rules of asepsis and antiseptics were observed. It was carried out a pathologic anatomical section, internal organs were selected for further research.

In the stabilized blood, morphological parameters were investigated: the number of erythrocytes, leukocytes, hematocrit, hemoglobin levels in the blood were determined nefelometrically by hemoglobin-cyanide method. The total amount of leukocytes and erythrocytes in the blood was examined on a Goryayev counting chamber network, The leukogram was derived on the basis of microscopy of blood smears with differential counting of various forms of leukocytes. To evaluate the functional activity of neutrophilic granulocytes, indicators were used which were determined by traditional methods: phagocytic activity, phagocytic index (intensity of phagocytosis). The evaluation of phagocytosis in vitro was carried out after $30 \mathrm{~min}$. after the start of incubation with the culture of microorganisms $E$. coli. The intensity of phagocytosis was judged by the index of phagocytic index (Vlizlo et al., 2012).

Biochemical indicators: total protein, creatinine, urea, activity of AsAT, AlAT, alkaline phosphatase (AP), GGT, amylase in blood serum was determined using a semiautomatic analyzer (HumaLyzer 3000) (Vlizlo et al., 2012).

The statistical processing of the results of experimental studies was carried out according to the program of statistical data analysis package in Microsoft Exel-97. Student's tcriterion was used to determine the probability of differences between the mean values.

\section{Results and discussion}

Already since the first days of the introduction of fumonisin morpho-functional state of animals gradually changed. Clinical picture of fumonisin toxicosis in experimental rats at day 14 was manifested by dermo-necrotic effect, was observed redness and formation of crust on visible mucous membranes, nose, was showed swelling and redness of the forelegs (Fig. 2).

A characteristic feature of all experimental rats, in our experiment, were swelling in the area of hip joints with the subsequent formation of abscesses. (Fig. 3). 

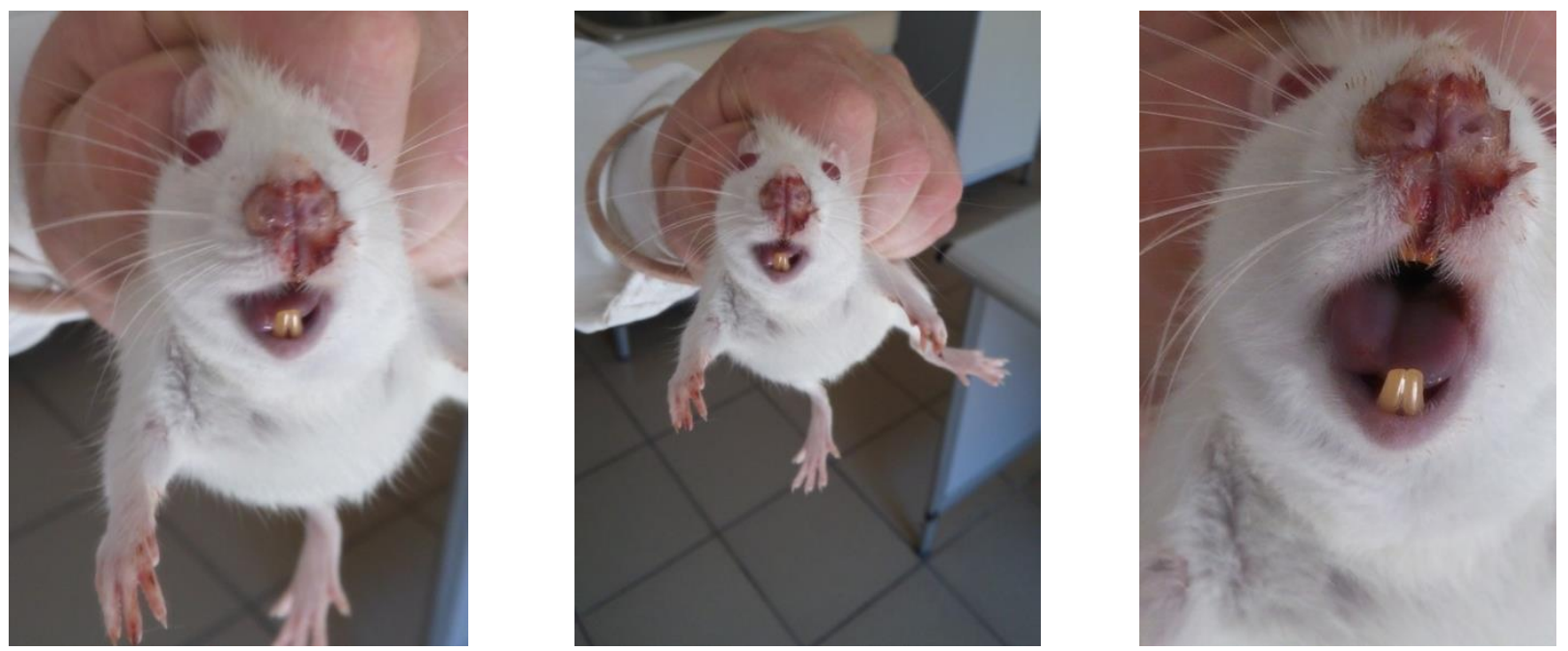

Fig. 2. Clinical manifestations of fumonisin toxicosis in rats of II, III, IV groups, formation of crust and hyperemia of visible mucous membranes
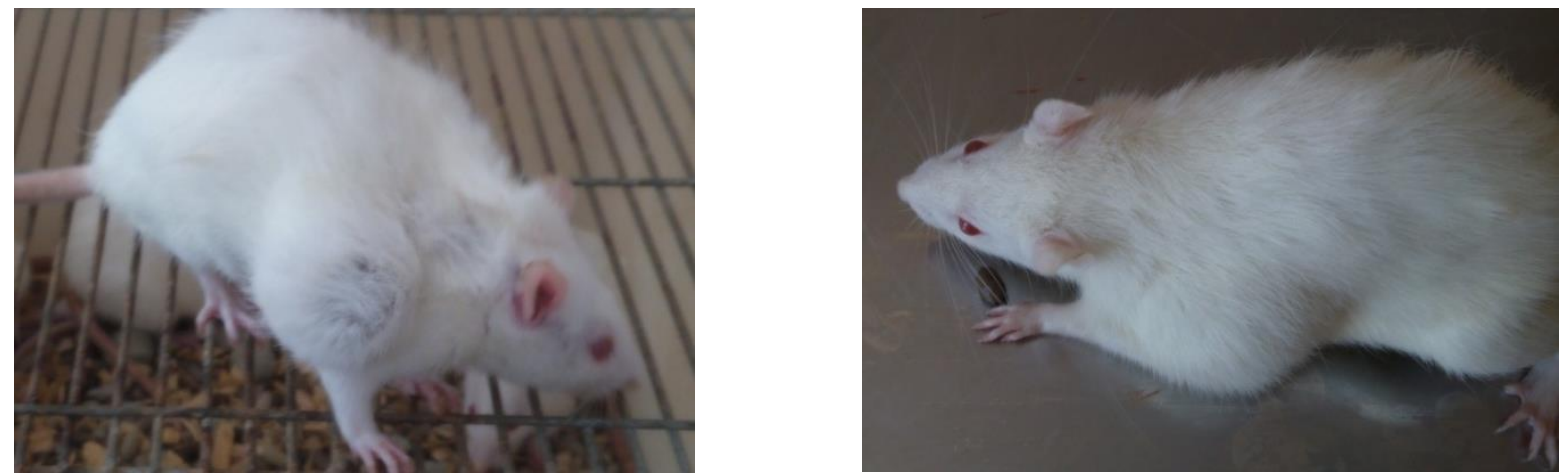

Fig. 3. Manifestations of toxicosis in rats, edema in joints in animals of II, III, IV groups

After the pathologic-anatomical section of the dead animals, hemorrhages of the thoracic muscles were detected. The obtained observation results during the experimental period are given in Table. 1

Table 1

Clinical observations of rats during the experiment $(M \pm m, n=40)$

\begin{tabular}{lcccc}
\hline \multicolumn{1}{c}{ Indexes } & \multicolumn{4}{c}{ Animal Groups } \\
\cline { 2 - 5 } & I control & II toxin & III toxin + X & IV toxin $\mathrm{H}+Ц$ \\
\hline Initial body weight, $\mathrm{g}$ & $121.9 \pm 2.7$ & $123.1 \pm 3.7$ & $122.3 \pm 7.1$ & $120.9 \pm 2.4$ \\
Body weight at the end, $\mathrm{g}$ & $122.0 \pm 2.7$ & $106.1 \pm 1.7$ & $120.4 \pm 5.7$ & $119.9 \pm 3.3$ \\
Body temperature, ${ }^{\circ} \mathrm{C}$ & $37.9 \pm 0.1$ & $36.5 \pm 0.5$ & $37.3 \pm 0.3$ & $37.5 \pm 0.4$ \\
Respiratory rate, movements / min. & $127 \pm 4$ & $143 \pm 9$ & $130 \pm 7$ & $132 \pm 2$ \\
Disorders of the digestive tract & absent & diarrhea & absent & absent \\
Pulse, movements / min. & $57 \pm 4$ & $69 \pm 9$ & $58 \pm 7$ & $59 \pm 2$ \\
Inadvertent reactions & absent & depressed & absent & absent \\
Animal death & absent & absent & absent & absent \\
\hline
\end{tabular}

Analyzing the dynamics of weight indicators of internal organs was established, that in the 2nd group, when the weight of the body of animals was reduced, the mass of the internal organs of rats was also increased. The results of determining the coefficients of the mass of internal organs on the 14th day of use of the HammecoTox $(\mathrm{H})$ and Zeolite (Z) sorbents are given in Table 2.
For the 21st day of the experiment, rats of III and IV groups according to general clinical parameters, behavior, attitude to feed, water, condition of external mucous membranes, as well as function of the digestive tract, urinary system did not differ from the animals of the control group.
As can be seen from the results of Table. 4 in rats of experimental group II for fumonisin toxicosis were significantly higher coefficients of weight of liver, lungs, kidneys and spleen compared to control group. These digital data in the table are confirmed by visual studies of the internal organs, in particular, the spleen (Fig. 4). 
Table 2

The coefficients of the mass of the internal organs of rats under conditions of fumonisin toxicosis at day 14 of the use of HammecoTox $(\mathrm{H})$ and Zeolith $(\mathrm{Z}),(\mathrm{M} \pm \mathrm{m}, \mathrm{n}=10)$

\begin{tabular}{lrrrc}
\hline \multirow{2}{*}{ Organs } & \multicolumn{4}{c}{ Animal Groups } \\
\cline { 2 - 4 } & I control & II toxin & III toxin+ H & IVtoxin+Z \\
\hline Liver & $33.9 \pm 0.2$ & $39.7 \pm 1.3^{*}$ & $36.5 \pm 1.5$ & $37.5 \pm 1.2$ \\
Lungs & $5.3 \pm 0.3$ & $9.3 \pm 2.1^{*}$ & $8.0 \pm 0.7^{*}$ & $8.4 \pm 0.4^{*}$ \\
Heart & $4.1 \pm 1.3$ & $3.5 \pm 0.1^{*}$ & $2.9 \pm 0.2^{* *}$ & $3.6 \pm 0.3$ \\
Left kidney & $2.7 \pm 0.1$ & $3.3 \pm 0.2^{*}$ & $2.8 \pm 0.1$ & $3,1 \pm 0,1$ \\
Right kidney & $2.5 \pm 0.0$ & $3.2 \pm 0.3^{*}$ & $2.7 \pm 0.1$ & $2,9 \pm 0,1$ \\
Kidneys & $2.6 \pm 0.1$ & $3.2 \pm 0.2^{*}$ & $2.7 \pm 0.1$ & $3,0 \pm 0,1$ \\
Spleen & $4.2 \pm 0.4$ & $5.2 \pm 0.5^{* *}$ & $4.5 \pm 0.5$ & $3,4 \pm 0,4$ \\
\hline
\end{tabular}

Note: hereafter: $*-\mathrm{P} \leq 0.05 ; * *-\mathrm{P} \leq 0.01$ in comparison with control

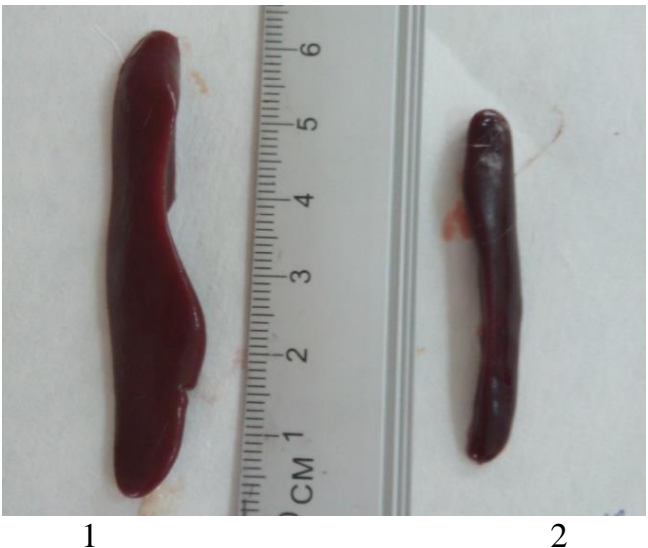

Fig. 4. Spleen of animals of group II for fumonisin toxicosis. 2. Spleen of animals of group IV for use of Zeolite (Z)

Under these conditions, internal organs of the liver, kidneys, spleen were not of typical form, flabby consistency, slurry of the pulp is excessive. On the section of the parenchyma goes beyond the contours, indicating an increase in the organ in general. At the same time, in rats of III and IV groups, after appropriate application of the investigated feed additives Hammeco Tox $(\mathrm{H})$ and Zeolite $(\mathrm{Z})$, was observed a probable decrease in cardiac mass coefficients, which indicates the compensatory processes that occur in the body, under the conditions of toxicosis against the background of the effects of sorbents.

In a comparative aspect, under the conditions of fumonisin toxicosis, the effects of HammecoTox $(\mathrm{H})$ and Zeolite $(\mathrm{Z})$ on the important parameters of homeostasis of the rat were carried out. The results of hematological studies are given in Table 3. After the analysis of the obtained results of hematological research on the 14th day in the rats of group II (Table 3) was found a probable increase in the number of leukocytes, established a tendency to increase, the number of eosinophils, segmental neutrophils, as well as a decrease in the number of lymphocytes, monocytes, compared with the control group. In the analysis of leukograms was noted a tendency to shift the nucleus to the left. These results indicated the presence of inflammatory processes and reduced immune protection of the organism of animals in general.

\section{Table 3}

Morphological parameters of blood of rats under conditions of fumonisin toxicosis at day 14 of use of HammecoTox $(\mathrm{H})$ and Zeolite $(\mathrm{Z}),(\mathrm{M} \pm \mathrm{m}, \mathrm{n}=10)$

\begin{tabular}{lcccc}
\hline \multirow{2}{*}{ Indexes } & \multicolumn{3}{c}{ Animal Groups } \\
\cline { 2 - 5 } & I control & II toxin & III toxin+ H & IVtoxin+ Z \\
\hline Hemoglobin, g/l & $131.2 \pm 10.9$ & $115.4 \pm 5.0$ & $133.0 \pm 9.4$ & $139.9 \pm 0.1$ \\
Erythrocytes, T/L & $7.7 \pm 0.1$ & $9.4 \pm 0.6$ & $9.0 \pm 1.2$ & $7.9 \pm 0.1$ \\
Hematocrit \% & $31.6 \pm 1.2$ & $28.0 \pm 0.6$ & $35.6 \pm 0.3$ & $37.0 \pm 1.5$ \\
Leucocytes, g/l & $8.0 \pm 1.7$ & $18.9 \pm 1.5 * *$ & $7.9 \pm 0.4$ & $9.0 \pm 0.3$ \\
Lymphocytes \% & $68.0 \pm 1.1$ & $56.0 \pm 2.0$ & $69.3 \pm 0.7$ & $71.3 \pm 1.7$ \\
Sticknuclei, \% & - & $2.0 \pm 0.0$ & - & $1.3 \pm 1.3$ \\
Segmented nuclei, \% & $21.5 \pm 7.2$ & $30.7 \pm 2.4$ & $20.7 \pm 0.7$ & $24.0 \pm 1.1$ \\
Monocytes, \% & $1.3 \pm 0.7$ & $0.7 \pm 0.7$ & $1.3 \pm 0.7$ & $2.0 \pm 1.1$ \\
Eosinophils, \% & $2.0 \pm 1.1$ & $6.7 \pm 0.7 *$ & $2.6 \pm 1.3$ & $1.3 \pm 0.7$ \\
\hline
\end{tabular}

At the same time, in the rats of groups III and IV, after the imposition of HammecoTox $(\mathrm{H})$ and Zeolite $(\mathrm{Z})$, these same indices were respectively close to the control group.

In particular, was found a tendency to increase the number of erythrocytes, lymphocytes and hematocrit levels compared to animals of the second group, indicating stimulation of the immune system. In particular, increasing the content of hemoglobin has a positive value, given the intensification of the processes of oxygen supplying the basic systems of vital activity of the organism. After analysis of leukocytes in the above-mentioned groups, the morphological parameters of blood did not go beyond the limits of physiological values and were close to the control animals. Their normalization indicates the state of inhibition of the inflammatory process, the enhancement of the activity of immune protection of the animal organism and the improvement of the clinical condition. Obviously, the stimulatory effect on the investigated parameters of hemopoiesis is due to the high biological action of the elements, which are part of the mineral feed supplement, which have a beneficial effect on the strengthening of the respiratory function, promote the flow of oxygen and intensify oxidation-reduction processes, as a result - the activation of metabolic processes and energy. 
Reactions that occur in the background of toxicosis are caused by selective tropism on various tissues of the body, resulting in neuro-, hepatotoxic and nephrotoxic reactions. Diagnosing such changes can be done after comprehensive study taking into account biochemical changes. The results of biochemical studies of blood in rats are shown in Table. 4 .

\section{Table 4}

Biochemical parameters of blood serum of rats for 14 days against the background of toxicosis and under conditions of use of HammecoTox $(\mathrm{H})$ and Zeolite $(\mathrm{Z}),(\mathrm{M} \pm \mathrm{m}, \mathrm{n}=10)$

\begin{tabular}{lcccc}
\hline \multirow{2}{*}{ Indexes } & \multicolumn{4}{c}{ Animal Groups } \\
\cline { 2 - 5 } & I control & II toxin & III toxin+ H & IVtoxin+ Z \\
\hline Total protein g/l & $79.6 \pm 1.4$ & $63.3 \pm 1.5^{*}$ & $81.8 \pm 2.7$ & $78.7 \pm 4.7$ \\
AlAt, un/l & $74.03 \pm 4.2$ & $66.2 \pm 6.5$ & $70.1 \pm 2.22$ & $69.0 \pm 8.4$ \\
AsAt, un/l & $226.9 \pm 24.8$ & $439.4 \pm 31.2^{*}$ & $235.4 \pm 38.1$ & $337.9 \pm 34.5$ \\
Lf, un/l & $290,8 \pm 21.9$ & $275.1 \pm 19.5$ & $291.7 \pm 9.1$ & $253.9 \pm 70.8$ \\
GGT, un/l & $2.0 \pm 1.0$ & $3.0 \pm 0.2^{*}$ & $1.9 \pm 0.3$ & $2.3 \pm 1.0$ \\
FAN, \% & $26.6 \pm 1.1$ & $22.3 \pm 4.3$ & $32.7 \pm 5.1$ & $35.2 \pm 5.8$ \\
FI, m.t/neutr. & $12.6 \pm 1.1$ & $9.9 \pm 1.0$ & $13.5 \pm 0.6$ & $13.4 \pm 0.5$ \\
Urea, mol/l & $5.6 \pm 0.6$ & $7.1 \pm 0.5$ & $4.9 \pm 0.7$ & $5.3 \pm 0.7$ \\
Creatinine, $\mu$ mol/l & $93.9 \pm 2.6$ & $111.4 \pm 0.8^{*}$ & $85.0 \pm 0.0$ & $86.9 \pm 3.2$ \\
Amylase, un/l & $1715 \pm 80.7$ & $2038 \pm 44.8$ & $1807.7 \pm 81.0$ & $1769.7 \pm 31.8$ \\
\hline
\end{tabular}

As the data indicates after the experiment (Table 4), in the body of rats of experimental groups, which were fed feed additives with food for a period of 14 days, the processes of transamination from alanine and aspartic acids took place at different intensities. In particular, in blood serum of rats of group III, the indicators were normalized and were approached the control group, and in rats of group IV was detected higher activity of AsAT, compared to the animals of the control group.

Taking into account that the activity of aminotransferases in the blood is related to their participation in the processes of protein synthesis, the use of free amino acids in the energy and plastic processes in the tissues of an organism that is intensively growing, the detected changes in the activity of enzymes confirm the activating effect of feed additives on the processes of intensification of the reamination of free amino acids, and, consequently, on the growth and development of animals. When evaluating the activity of AsAT, AlAT and AP, activity of transaminases decreased in both experimental groups, while the indicators of AP activity did not undergo significant changes. There was a tendency to increase AsAT in rats of group IV compared with the control group, but, considering allowable fluctuations of the indexes of investigated enzymes, it can be assumed that they are not beyond the magnitude of physiological boundaries (Khariv et al., 2016; Guta, 2016; Gutyj et al., 2017).

The higher activity of AsAT and AlAT in rats of group II was established, it may indicate increased permeability of

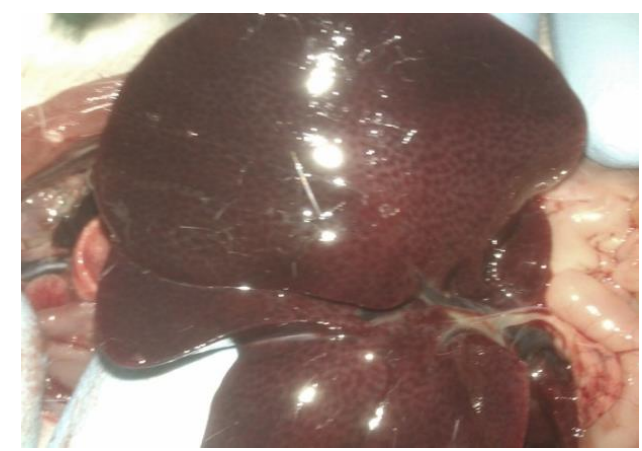

Liver, multiple point hemorrhages cells under the influence of fumonisin, which directly affects the membrane, possibly breaking their structural components.

The established dynamics of activity of investigated enzymes in rats of groups III and IV indicates the stability of membrane structures of hepatocytes and indicates the positive functionality of the liver in the use of these agents, the restoration of the structure of hepatocyte membranes and the absence of their hepatotoxic effects on the body. The activity of enzymes indicates the preservation of the liver's protein synthesis function and the absence of degradation of hepatocyte membranes.

Regarding the urea and creatinine content in blood serum of rats of group III and IV, no significant differences were found between the experimental and control groups.

The concentration of creatinine and urea in animals of the second group exceeded the physiological values, which was a clinical sign of the development of inflammatory process in the body of rats against the background of toxicosis. The biochemical picture of blood serum was confirmed by pathological and anatomical changes, in particular, on the autopsy it is visible that the kidneys are of dark cherry color, the border between the cortical and brain zone is erased. All changes in the kidneys indicate a violation of the function of filtration and absorption, as well as from the side of the liver, which was dark cherry color with multiple hemorrhages, and inflammatory points (Fig. 5).

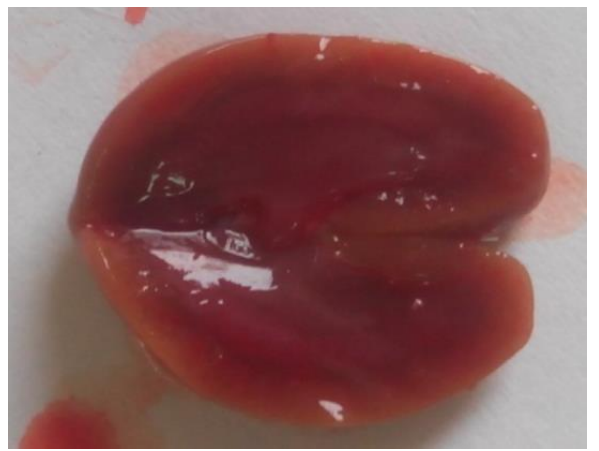

The kidneys are hyperemic, the border between the cortical and the brain is erased

Fig. 5. Internal organs of rats of group II on the 14th day of fumonisin toxicosis 
As to the indicators that characterize the immunophysiological status, then on the 14th day of application of HammecoTox $(\mathrm{H})$ and Zeolite $(\mathrm{Z})$, in all experimental groups a positive trend was observed for the increase of the total amount of serum protein and its albumin fraction, indicating the intensity of protein metabolism in the rat (Table 5).

Analysis of cell-level indices of nonspecific resistance showed that in animals under conditions of toxicosis and after application of feed additives at 14 days, phagocytic activity of neutrophils and phagocytic index increased, indi- cating changes in the immune system of animals. When in rats of group 2, the syndrome of "lazy phagocytes" was noted, indicating the inhibition of the immune system. Taking into account the studied blood parameters, it can be argued that the applied feed additives did not show immunosuppressive effects on the body of rats. In general, there was moderate activation of the cellular level of animal immunity, which in general had a positive effect on the course of fumonisinotoxicosis and improved the clinical status of rats.

\section{Table 5}

Indices of immunophysiological status of rats under conditions of toxicity for 14 days with the use of feed additives $(\mathrm{M} \pm \mathrm{m}, \mathrm{n}=10)$

\begin{tabular}{|c|c|c|c|c|}
\hline \multirow{2}{*}{ Indexes } & \multicolumn{4}{|c|}{ Animal Groups } \\
\hline & I control & II toxin & III toxin $+\mathrm{H}$ & IVtoxin $+\mathrm{Z}$ \\
\hline Albumin, $\%$ & $52.03 \pm 1.8$ & $38.9 \pm 2.4^{*}$ & $48.3 \pm 2.1$ & $49.0 \pm 1.5$ \\
\hline$\alpha_{1}$-globulin, $\%$ & $3.9 \pm 0.5$ & $5.6 \pm 0.7 *$ & $8.1 \pm 0.2 *$ & $8.1 \pm 0.2 *$ \\
\hline$\alpha_{2}$-globulin, $\%$ & $7.1 \pm 0.8$ & $7.1 \pm 0.1$ & $12.4 \pm 1.4^{*}$ & $12.4 \pm 1.4^{*}$ \\
\hline$\beta$-globulin, $\%$ & $17.9 \pm 1.3$ & $18.8 \pm 0.3$ & $27.4 \pm 2.5^{*}$ & $27.4 \pm 2.4 *$ \\
\hline$\gamma$-globulin, $\%$ & $19.1 \pm 2.3$ & $19.6 \pm 1.7$ & $16.3 \pm 2.1$ & $16.3 \pm 2.0$ \\
\hline
\end{tabular}

In the protein spectrum of blood serum of rats, a slight decrease in the albumin fraction in all experimental groups was established. Under conditions of application of Hammeco Tox and Zeolite in the blood serum of experimental animals, a gradual increase in albumin content was observed, which had a positive prognostic value and showed improvement in the clinical condition of animals. Growth of globulin fractions in animals of these groups indicates the stimulation of immune defense functions.

Reducing the total protein content during fumonisin toxicosis indicates the development of protein metabolism disturbances in the body of animals. The low albumin content in the experimental groups, as well as the low ratio of albumin/globulin fractions, indicates the clinical signs of impairment of the functioning of the digestive system of investigated animals, which is also confirmed in the autopsy. Obviously, in this process, there were functional changes in the liver of investigated animals. In particular, increased activity of the AsAT enzyme indicates a violation of the integrity of the liver cells (Gutyj et al., 2018). This is especially true in animals of the second experimental group, as evidenced by an increase in GGT activity, which reflects the state of the liver and hepatobiliary tract.

\section{Conclusions}

After use of feed additives of HammecoTox and Zeolite under conditions of fumonisin toxicosis, especially should be noted the stabilization of hematological parameters, the content of hematocrit, the number of leukocytes, the increase in the content of eosinophils and lymphocytes, which reflects the activation of hematopoesis in the organism of experimental animals and its protective factors. An increase in the urea content in these groups indicates the recovery of urea-synthesis and urea-excretory liver function.

In general, during the period of the conducted searches, the effectiveness of both feed additives in the experimental fumonisin toxicosis was established, and noted more active processes of normalization of the clinical condition of experimental rats after use of HammecoTox, due to the complex influence of the agent on the organism of animals.

Comparative preclinical tests have shown that the effectiveness of the feed additive Zeolite is slightly inferior to Hammeco Tox.

\section{References}

Berezovskyi, A.V., Fotina, T.I., Dvorska, Yu.Ie., \& Rozputnia, O.A. (2014). Suchasni detoksykanty mikotoksyniv: analiz vitchyznianoho rynku. Naukovyi visnyk veterynarnoi medytsyny, 13, 37-41. http://nbuv.gov.ua/UJRN/nvvm_2014_13_12 (in Ukrainian).

Brezvyn, O., Otchych, V., \& Kotsiumbas, I. (2013). Kontrol mikotoksyniv u kormakh i yikh zneshkodzhennia. Visnyk Lvivskoho universytetu. Ser.: Biolohichna, 62, 242-249. http://nbuv.gov.ua/UJRN/VLNU_biol_2013_62_32 (in Ukrainian).

Fravalo, P., Oswald, I.P., Salvat, G., Pinton, P., Postollec, G., Queguiner, M., Cariolet, R., Boilletot, E., Guerre, P., Tanguy, M., \& Burel, C. (2013). Effect of Low Dose of Fumonisins on Pig Health: Immune Status, Intestinal Microbiota and Sensitivity to Salmonella. Toxins, 5(4), 841-864. doi: 10.3390/toxins5040841.

Grenier, B., Dohnal, I., Shanmugasundaram, R., Eicher, S.D., Selvaraj, R.K., Schatzmayr, G., \& Applegate, T.J. (2016). Susceptibility of Broiler Chickens to Coccidiosis When Fed Subclinical Doses of Deoxynivalenol and Fumonisins-Special Emphasis on the Immunological Response and the Mycotoxin Interaction. Toxins, 8(8), 231 doi: 10.3390/toxins8080231.

Guerre, P. (2015). Fusariotoxins in Avian Species: Toxicokinetics, Metabolism and Persistence in Tissues. Toxins, 7(6), 22892305. doi: 10.3390/toxins7062289.

Guta, Z. (2016). The influence of fumonisin toxicity on morphological and biochemical blood parameters in rats. Scientific Messenger LNUVMBT named after S.Z. Gzhytskyj, 18, 2(66), 48-51. doi: 10.15421/nvlvet6611 (in Ukrainian).

Guta, Z.A. (2015). Do metodyky vyvchennia vplyvu fumonizyniv na orhanizm tvaryn ta ptytsi. Naukovyi visnyk Lvivskoho natsionalnoho universytetu veterynarnoi medytsyny ta biotekhnolohii, 17(2), 37-43. https://nvlvet.com.ua/index.php/ journal/article/view/457 (in Ukrainian).

Gutyj, B., Hariv, I., Gunchak, V., Sobolta, A., Prijma, O., \& Iesina, E. (2018). The influence of «Amprolinsile» and brovitacoccide on the activity of blood serum enzymes by the eumeriosic invasion. Scientific Messenger of Lviv National University of Veterinary Medicine and Biotechnologies, 20(83), 51-55. doi: 10.15421/nvlvet8310.

Ukrainian Journal of Veterinary and Agricultural Sciences, 2018, Vol. 1, N 1 
Gutyj, B., Martyshchuk, T., Bushueva, I., Semeniv, B., Parchenko, V., Kaplaushenko, A., Magrelo, N., Hirkovyy, A., Musiy, L., \& Murska, S. (2017). Morphological and biochemical indicators of blood of rats poisoned by carbon tetrachloride and subject to action of liposomal preparation. Regulatory Mechanisms in Biosystems, 8(2), 304-309. doi: 10.15421/021748.

Hoister, O.S., Dziadevych, S.V., \& Minchenko, O.H. (2013). Zastosuvannia suchasnykh biosensornykh tekhnolohii v ekotoksykolohichnomu monitorynhu deiakykh toksykantiv pryrodnoho (mikotoksyny) ta antropohennoho (pestytsydy) pokhodzhennia. Chastyna I. Mikotoksyny. Sensorna elektronika $i$ mikrosystemni tekhnolohii, 10(3), 55. http://nbuv.gov.ua/UJRN/seimt_2013_10_3_10 (in Ukrainian).

Khariv, M., Gutyj, B., Butsyak, V., \& Khariv, I. (2016). Hematological indices of rat organisms under conditions of oxidative stress and liposomal preparation action. Biological Bulletin of Bogdan Chmelnitskiy Melitopol State Pedagogical University, 6 (1), 276-289. doi: 10.15421/201615.

Kim, D.H., Lee, I.H., Do, W.H., Nam, W.S., Li, H., Jang, H.S., \& Lee, C. (2013). Incidence and levels of deoxynivalenol, fumonisins and zearalenone contaminants in animal feeds used in Korea in 2012. Toxins, 6(1), 20-32. doi: 10.3390/toxins6010020.

Kotsiumbas, I.Ia. Brezvyn, O.M., \& Kushnir, R.O. (2010). Vyvchennia dezintoksykuiuchykh vlastyvostei alfasorbu pry eksperymentalnomu hostromu T-2 toksykozi u shchuriv. Veterynarna medytsyna, 93, 230-236. http://nbuv.gov.ua/UJRN/vetmed_2010_93_49 (in Ukrainian).

Nleya, N., Adetunji, M.C., \& Mwanza, M. (2018). Current Status of Mycotoxin Contamination of Food Commodities in Zimbabwe. Toxins (Basel), 10(5), pii: E89. doi: 10.3390/toxins10050089.

Ruda, M.Ie. \& Vasianovych, O.M. (2012). Vyvchennia detoksykatsiinoi dii sorbentnykh preparativ invitro vidnosno kultury hrybiv-produtsentiv mikotoksyniv. Veterynarna biotekhnolohiia, 21, 115-121. http://nbuv.gov.ua/UJRN/ vbtb_2012_21_23 (in Ukrainian).

Vlizlo, V.V., Fedoruk, R.S., \& Ratych, I.B. (2012). Laboratorni metody doslidzhen u biolohii, tvarynnytstvi ta veterynarnii medytsyni: dovidnyk. Lviv: Spolom (in Ukrainian). 